\title{
Acta Cirúrgica Brasileira em 2012. Análise retrospectiva
}

\section{Saul Goldenberg}

Fundador e Editor Chefe

A partir de 2012 a Acta Cirúrgica Brasileira passou a ser mensal.

Em 2012 foram publicados 12 fascículos da Acta Cirúrgica Brasileira.

Artigos originais disponíveis em www.scielo.br/acb

Idioma de divulgação: em inglês

\author{
Número de artigos por mês: \\ Janeiro.:15 Julho: Um editorial e 14 artigos \\ Fevereiro:17 Agosto: 13 \\ Março: 13 Setembro: 12 \\ Abril: 13 Outubro: 13 \\ Maio: 12 Novembro: 13 \\ Junho: 13 Dezembro: Um editorial e 14 artigos
}

TOTAL DE ARTIGOS: Dois editoriais e 162 originais: 139 nacionais e 23 internacionais.

\section{PROCEDÊNCIA \\ DO BRASIL}

\section{SÃO PAULO}

Universidade de São Paulo (USP)

\section{Postgraduate Program in Thoracic and}

Cardiovascular Surgery - Faculty of Medicine.

Postgraduate Program in Medicine - Surgical Clinic.

Postgraduate Program in Internal Medicine - Faculty of Medicine of Ribeirao Preto.

Postgraduate Program in Oftalmology, Otorrhinolaryngology and Head Neck Surgery - Department of Oftalmology, Faculty of Medicine of Ribeirao Preto.

Postgraduate Program in Surgery - Laboratory of Pharmacology, Department of Pathology and Animal Hospital, Faculty of Veterinary Medicine.

Department of Gastroenterology, Experimental Surgery Laboratory, LIM-37/LIM-51, Faculty of Medicine.
Experimental Laboratory, Department of Maxillofacial Surgery, Prosthetics and Traumatology, School of Dentistry.

Experimental and Technical Surgery Laboratory, Surgery and Anatomy Department, Faculty of Medicine of Ribeirao Preto.

Laboratory of Neuroanatomy, Department of Surgery and Anatomy, Faculty of Medicine of Ribeirao Preto.

\section{$\underline{\text { Universidade Federal de São Paulo (UNIFESP) }}$}

Postgraduate Program in Plastic Surgery - Department of Surgery.

Postgraduate Program in Interdisciplinary Surgical Science - Department of Surgery.

Department of Morphology, Laboratory of Histology and Structural Biology.

Department of Surgery, Division of Operative Technique and Experimental Surgery.

Department of Pathology, Investigative Pathology Division. 
Department of Surgery, Division of Plastic Surgery.

Department of Surgery, Surgical Gastroenterology Division.

\section{$\underline{\text { Universidade Estadual de São Paulo (UNESP) }}$}

Postgraduate Program in General Basis of Surgery Botucatu School of Medicine.

Experimental Laboratory of Anesthesiology, Botucatu School of Medicine.

Experimental Surgery Laboratory, Department of Surgery and Orthopedics, Botucatu School of Medicine.

Division of Coloproctology, Department of Surgery, Botucatu School of Medicine.

Department ofClinics, Surgery and Animal Reproduction, Division of Veterinary Surgical Technique.

Laboratory of School of Veterinary Medicine and Animal Science.

\section{Universidade de Campinas (UNICAMP)}

Postgraduate Program in Surgical Sciences - Faculty of Medical Sciences, Laboratory of Molecular Oncology and Science Surgery Area, Department of Surgery, Faculty of Medical Sciences.

Laboratory of Enzymology and Experimental Carcinogenesis, Experimental Surgery and Medicine Division, Faculty of Medical Sciences.

Laboratory of Experimental Anesthesia.

Surgical Technique and Experimental Surgery Laboratory, Medical Sciences School.

Faculdade de Ciências Médicas da Santa Casa de São $\underline{\text { Paulo (FCMSCSP) }}$

Postgraduate Program in Research Surgery - Faculty of Medical Sciences.

\section{RIO GRANDE DO SUL}

Postgraduate Program in Sciences of Gastroenterology

and Hepatology - School of Medicine, Experimental Gastroenterology and Hepatology Laboratory, Experimental Research, UFRGS.

Institute of Cardiology, Cardiology University Foundation (IC/FUC).

\section{CEARÁ}

Postgraduate Program in Surgery - Laboratory of Experimental Surgery, Department of Surgery, Faculty of Medicine, UFC.

Experimental Surgery Research Laboratory, Department of Surgery, UFC.

Experimental Animal Laboratory of Department of Surgery, Faculty of Medicine, UFC.

Department of Mastology, UFC.

\section{MATO GROSSO DO SUL}

Postgraduate Program in Health and Development in the West Central Region - UFMS.

School of Medicine, Surgery Department, UFMS.

\section{BRASILIA}

\section{Postgraduate Program in Medical Sciences -} Laboratory of Experimental Surgery, School of Medicine, UnB. Experimental Laboratory of Surgery, School of Medicine, UnB.

\section{PERNAMBUCO}

Postgraduate Program in Health Sciences - UPE.

Postgraduate Program in Oral and Maxillofacial Surgery - UPE.

Postgraduate Program in Surgery - Center for Experimental Surgery, Department of Surgery, UFPE. 
Laboratory of Experimental Surgery, UFPE.

Animal Department of Pharmacy, UFPE.

Division of Abdominal Surgery, Department of Surgery, UPE.

\section{MINAS GERAIS}

Postgraduate Program in Surgical and Ophthalmological Applied Sciences - UFMG.

Department of Surgery, Laboratory of Experimental Surgery, School of Medicine, UFMG.

Wild Animals Research Laboratory, School of Veterinary, UFU.

Department of Surgery, School of Medicine, UFTM.

\section{RIO DE JANEIRO}

Postgraduate Program in Surgical Science Experimental Surgical Center, Department of Surgery, School of Medicine, UFRJ. UFRJ.

Postgraduate Program in Nuclear Engineering -

Postgraduate Program in Pathology - School of Medicine, UFF.

Postgraduate Program in Medical Sciences - School of Medicine, UFF.

\section{PARANÁ}

Postgraduate Program in Principles of Surgery Department of Surgery, FEPAR.

Postgraduate Program in Clinical Surgery Department of Surgery, UFPR.

Division of Surgical Technique and Experimental Surgery, UFPR.

\section{GOIÁS}

Postgraduate Program in Health Sciences - Laboratory of Experimental Surgery and Anesthesiology, School of Veterinary and Animal Science, UFG.

\section{PARÁ}

Experimental Surgery Laboratory. School of Medicine, UEPA

\section{SANTA CATARINA}

Laboratory of Technique and Experimental Surgery, Department of Surgery and Laboratory of Pathology, UFSC.

\section{MARANHÃO}

Department of Medicine, School of Medicine, UFMA.

\section{DO EXTERIOR}

\section{CHINA}

Department of Urology, Sun Yat-sen University, Guangzhou.

Department of Pain, Xuanwu Hospital, Capital Medical University, Xuanwu District, Beijing.

Department of Sugery, $1^{\text {st }}$ Clinical Center of Guangdong Medical College, Zhanjiang, Guangdong.

Department of Orthopaedic Surgery, School of Medicine, Shanghai Jiao Tong University, Affiliated Renji Hospital.

Department of Orthopedics, Central Hospital of Yiwu City.

Department of Anesthesiology, People's Hospital of Guizhou Province.

Central Laboratory, Affiliated Hospital of Shandong Academy of Medical Science.

Department of Orthopedics, General Hospital of Jinan Military Command, Jinan.

Department of Neurosurgery, The Affiliated Hospital of Taishan Medical College, Taishan.

Experimental Center, Third Xiangya Hospital, Central South University, Changsha. 


\section{IRAN}

Department of Clinical Sciences, Faculty of Veterinary Medicine, Sanandaj Branch, Islamic Azad University, Sanandaj.

Department of Veterinary Surgery, Faculty of Specialized Veterinary Sciences, Science and Research Branch, Islamic Azad University, Tehran.

Department of Experimental Surgery, Faculty of Veterinary, Islamic Azad University (IAU), Kahnooj Branch, Kerman.

\section{TURKEY}

Experimental Medical Research Center, Istanbul University.

Postgraduate Program in Neurosurgery, First Neurosurgery Clinic in Bakirkoy Mental Diseases Hospital, Bakirkoy.

Experimental Animal Laboratory, Gulhane Military Medical Academy, Ankara.

Department of Nuclear Applications, Institute of Nuclear Sciences, Ege University, Bornova, Izmir-Turkey and Adnan Menderes University, Science \& Technology Research \& Development Central, Aydin.

Experimental Medical Research Center, Istanbul University.

Experimental Medical Research Center Bezmialem Vakif University, Surgery, İstanbul.

\section{HUNGARY}

Department of Operative Techniques and Surgical Research, Department of Surgery, Medical and Health Science Center, University of Debrecen.

\section{KOREA}

Department of Health Administration Namseoul University, Chungnam.

\section{FRANCE}

Laboratory of the Institute of Developmental Biology and Cancer, Unité Mixte de Recherche (UMR) 6543, Centre National de la Recherche Scientifique (CNRS), University of Nice Sophia-Antipolis.

\section{CZECH REPUBLIC}

Department of Surgery, University Hospital Bulovka, Charles University Prague.

\section{MEXICO}

Lung Transplantation Research Unit, National Institute of Respiratory Diseases “Ismael Cosio Villegas".

\section{Considerações finais}

A Acta Cirúrgica Brasileira publicou 97,5\% de artigos originais, nacionais e internacionais.

Tempo médio entre recebimento do original do artigo e sua publicação não ultrapassou quatro a seis meses.

Eleita pelos Coordenadores dos Programas de PósGraduação da Medicina III - Cirurgia da CAPES como a revista da área.

\section{Conceito CAPES: QUALIS A2 \\ JCR Science Edition: FI 0,584 Apoio: CNPq}

Indexação: nas principais Base de Dados: LILACS, SciELO, Medline/PubMed, ISI Web of Science, JCR Science Edition, Excerpta Medica-EMBASE, Scopus, Latindex, Biblioteca Universia, CAB Abstracts, Directory Access Journals, Free Full Text, Google Academic.

Público alvo: Docentes, Pesquisadores, Programas de Pós-Graduação, Cirurgiões, Bibliotecas Biomédicas.

Nível de interesse crescente pela revista, do Brasil e do exterior.

Mais um ano com a tarefa cumprida e o objetivo alcançado. 